\title{
Technological characterization and survival of the exopolysaccharide-producing strain Lactobacillus delbrueckii subsp. lactis 193 and its bile-resistant derivative $193+$ in simulated gastric and intestinal juices
}

\author{
Patricia Burns ${ }^{1,2}$, Gabriel Vinderola ${ }^{2}$, Jorge Reinheimer ${ }^{2}$, Isabel Cuesta ${ }^{1}$, Clara G de los Reyes-Gavilán ${ }^{1 *}$ \\ and Patricia Ruas-Madiedo ${ }^{1}$

\footnotetext{
${ }^{1}$ Instituto de Productos Lácteos de Asturias-Consejo Superior de Investigaciones Científicas (IPLA-CSIC), Departamento de Microbiología y Bioquímica de Productos Lácteos. Carretera de Infiesto s/n, 33300 Villaviciosa, Asturias, Spain

${ }^{2}$ Instituto de Lactología Industrial (INLAIN, UNL-CONICET), Facultad de Ingeniería Química, Universidad Nacional del Litoral, $1^{\circ}$ de Mayo 3250, Santa Fe (3000), Argentina
}

Received 04 January 2011; accepted for publication 14 May 2011

\begin{abstract}
The capacity of lactic acid bacteria to produce exopolysaccharides (EPS) conferring microorganisms a ropy phenotype could be an interesting feature from a technological point of view. Progressive adaptation to bile salts might render some lactobacilli able to overcome physiological gut barriers but could also modify functional properties of the strain, including the production of EPS. In this work some technological properties and the survival ability in simulated gastrointestinal conditions of Lactobacillus delbrueckii subsp. lactis 193, and Lb. delbrueckii subsp. lactis $193+$, a strain with stable bile-resistant phenotype derived thereof, were characterized in milk in order to know whether the acquisition of resistance to bile could modify some characteristics of the microorganism. Both strains were able to grow and acidify milk similarly; however the production of ethanol increased at the expense of the aroma compound acetaldehyde in milk fermented by the strain $193+$, with respect to milk fermented by the strain 193. Both microorganisms produced a heteropolysaccharide composed of glucose and galactose, and were able to increase the viscosity of fermented milks. In spite of the higher production yield of EPS by the bile-resistant strain $193+$, it displayed a lower ability to increase viscosity than $L b$. delbrueckii subsp. lactis 193 . Milk increased survival in simulated gastric juice; the presence of bile improved adhesion to the intestinal cell line HT29-MTX in both strains. However, the acquisition of a stable resistance phenotype did not improve survival in simulated gastric and intestinal conditions or the adhesion to the intestinal cell line HT29-MTX. Thus, Lb. delbrueckii subsp. lactis 193 presents suitable technological properties for the manufacture of fermented dairy products; the acquisition of a stable bile-resistant phenotype modified some properties of the microorganism. This suggests that the possible use of bile-resistant derivative strains should be carefully evaluated in each specific application considering the influence that the acquisition of a stable bile-resistant phenotype could have in survival ability in gastric and intestinal conditions and in technological properties.
\end{abstract}

Keywords: exopolysaccharides, Lactobacillus delbrueckii subsp. lactis, bile, gastric juice, intestinal juice.

Lactobacillus delbrueckii is an important species for food fermentation. Lb. delbrueckii subsp. bulgaricus is essential for the production of yoghurt whereas $L b$. delbrueckii subsp.

For correspondance; e-mail:greyes_gavilan@ipla.csic.es lactis is mostly used in the manufacture of hard cheeses (Giraffa et al. 1998). Some authors have reported that Lb. delbrueckii is rarely found among the gut microbiota after ingestion due to its reduced capability to survive the restrictive conditions found during gastrointestinal digestion (Tannock, 2003; Wall et al. 2007). However, other researchers have provided evidence indicating that a 
proportion of these microorganisms can survive the gastrointestinal transit (GIT) (Marteau et al. 1997; Lick et al. 2001; Mater et al. 2005; Elli et al. 2006). In the same way, we have recently found that a small fraction of $L b$. delbrueckii subsp. lactis can survive simulated GIT when administered with milk (Burns et al. 2010).

Some strains of lactic acid bacteria (LAB) are able to produce exopolysaccharides (EPS). When produced in milk during fermentation by starter cultures, some of these polymers contribute to improve the sensory and structural properties of fermented products (Ruas-Madiedo et al. 2009b). EPS from LAB can generally be divided into homopolysaccharides (HoPS), which are polymers composed of one type of monosaccharide, and heteropolysaccharides (HePS), which are polymers of repeating units that are composed of two or more types of monosaccharides. A great diversity of HePS seems to exist among LAB regarding composition, structure and functionality (Mozzi et al. 2006; Ruas-Madiedo et al. 2009c).

Some Gram-positive bacteria can develop an adaptive response in the presence of moderate stress conditions. In previous works we reported on the isolation, molecular and functional characterization of $L b$. delbrueckii subsp. lactis bile-resistant derivatives (Burns et al. 2008, 2010). The acquisition of stable resistance to bile could facilitate the arrival of these microorganisms to the intestine and the possibility to produce there, bacterial enzymes that can improve the digestion of nutrients, such as the $\beta$-galactosidase, or that can liberate bioactive peptides from caseins (Gilliland, 1998; Hebert et al. 2008). However, it has been shown that the acquisition of bile tolerance can also modify other physiological and functional properties of the bile-adapted strain (Noriega et al. 2004; Guglielmotti et al. 2007; Sánchez et al. 2008), including the production of EPS (Ruas-Madiedo et al. 2009a).

The strain Lb. delbrueckii subsp. lactis 193 and its bile resistant derivative $L b$. delbrueckii subsp. lactis $193+$ were described in a previous work (Burns et al. 2008). Whereas the parental strain 193 showed no appreciable growth in the presence of $0.3 \%$ bile salts, the derivative $193+$ displayed active growth in medium containing $0.5 \%$ bile salts (Burns et al. 2008). The aim of the present study was to characterize the technological properties and the ability to survive simulated gastric and intestinal conditions of $L b$. delbrueckii subsp. lactis 193 in milk, and to know whether the acquisition of a stable phenotype of resistance to bile could modify these properties.

\section{Material and Methods}

\section{Bacterial strains and growth conditions}

The strain Lb. delbrueckii subsp. lactis 193 and its bile resistant derivative 193 + (Burns et al. 2008) were used in this study. Strains were grown in MRS (BioKar Diagnostics, Beauvais, France) at $37^{\circ} \mathrm{C}$ in a microaerophilic atmosphere containing $5 \%(\mathrm{v} / \mathrm{v}) \mathrm{CO}_{2}$; bacterial stocks were kept at $-80^{\circ}$ $\mathrm{C}$ in MRS containing $200 \mathrm{ml}$ glycerol per litre. As standard procedure, strains were cultured overnight from $-80^{\circ} \mathrm{C}$ stocks and employed to inoculate $(2 \% \mathrm{v} / \mathrm{v})$ fresh MRS medium that was incubated for $24 \mathrm{~h}$ for its use in experiments performed in this work.

For specific purposes, strains were also grown in commercial pasteurized milk (Central Lechera Asturiana, Asturias, Spain) which was supplemented with $1 \%(\mathrm{w} / \mathrm{v})$ Difco ${ }^{\mathrm{TM}}$ skimmed milk (Becton Dickinson, MD, USA) and pasteurized again at $90^{\circ} \mathrm{C}$ for $5 \mathrm{~min}$. MRS cultures of each strain were washed twice with sterile PBS buffer $\mathrm{pH} 7 \cdot 0$ and were used to inoculate $(2 \% \mathrm{v} / \mathrm{v}) 500 \mathrm{ml}$ pasteurized milk which was incubated overnight $(17 \pm 1 \mathrm{~h})$ in a water bath at $37^{\circ} \mathrm{C}$. Following fermentation, a sample was collected in sterile conditions for bacterial counting, fermented milks were cooled-down afterwards to approximately $18^{\circ} \mathrm{C}$ with running tap water, and then they were stirred 20-times up and down with a spoon. After sample collection for several analyses, the stirred fermented milks were stored overnight at $4{ }^{\circ} \mathrm{C}$. Three replicated batches of fermented milks were performed for each strain.

\section{Metabolic activity of strains in milk}

For bacterial counts, serial dilutions of cultured milks were made in Ringer's solution (Merck, Darmstadt, Germany), deep-plated on agar-MRS and incubated at $37^{\circ} \mathrm{C}$ for $2 \mathrm{~d}$. Counts were expressed as log cfu/g and the increase of the log units during milk fermentation was calculated. The $\mathrm{pH}$ of the fermented milks was directly measured with a MicropH 2001 pHmeter (Crison Instruments S.A., Barcelona, Spain).

Lactose consumption and organic acids production was determined by ion-exchange chromatography. A HPLC chromatographic system composed of an Alliance 2690 module injector, a Photodiode Array PDA 996 detector, a 410 refractive index (RI) detector and the Empower software (Waters, Milford, MA, USA) was used. The sample preparation and chromatographic conditions described by Salazar et al. (2009) were used. Results were expressed in $\mathrm{mm}$.

The volatile compounds in fermented milks were determined by means of a Head-Space (HS) GC-MS using a $6890 \mathrm{~N}$ Agilent GC coupled with a HS automatic injector G1888 series and with a 5975B inert MS detector (Agilent Technologies Inc., Palo Alto, CA, USA). Data was collected and analyzed with the Enhanced ChemStation G1701 software (Agilent). Sample preparation and chromatographic conditions were those previously described by Salazar et al. (2009). Results were expressed as $\mu \mathrm{g} / \mathrm{ml}$.

The apparent viscosity of stirred-fermented milks was measured using a Posthumus funnel (Hellinga et al. 1989). The funnel was filled with approximately $450 \mathrm{~g}$ stirredfermented milk and the time (in seconds) taken to pass the mark inside the funnel was recorded. The measurements were carried out in a chamber refrigerated at $4{ }^{\circ} \mathrm{C}$. 


\section{Production of exopolysaccharides (EPS) in milk}

The EPS fraction of fermented milks was isolated by mixing $40 \mathrm{~g}$ cultured milk with $10 \mathrm{ml}$ of a $60 \%$ TCA solution and strongly stirred for $45 \mathrm{~min}$ at room temperature. Precipitated bacteria and proteins were removed by centrifugation $\left(10000 \mathrm{~g}, 4{ }^{\circ} \mathrm{C}, 30 \mathrm{~min}\right)$ and the $\mathrm{pH}$ of supernatant was raised to $4 \cdot 5 \pm 0 \cdot 5$. Finally, supernatants were intensively dialyzed for $3 \mathrm{~d}$, with daily changes of ultrapure water, using dialysis tubes (Sigma Chemical Co., St. Luis, MO, USA) of molecular weight cut off 12-14 kDa and they were finally freeze-dried. To increase the purity level of the EPS fraction an additional procedure was applied. The initial EPS fraction was dissolved at $5 \mathrm{mg} / \mathrm{ml}$ in a buffer $(50 \mathrm{~mm}$-Tris$\mathrm{HCl}, 100 \mathrm{~mm}-\mathrm{MgSO}_{4} \cdot 7 \mathrm{H}_{2} \mathrm{O}, \mathrm{pH} 7 \cdot 5$ ) containing $2 \cdot 5 \mu \mathrm{g} / \mathrm{ml}$ of DNAse type I (Sigma) and incubated at $37^{\circ} \mathrm{C}$ for $6 \mathrm{~h}$. Afterwards, pronase E from Streptomyces griseus (Sigma) dissolved in $50 \mathrm{~mm}$-Tris-HCl, 2\% EDTA, pH 7.5 was added $(50 \mu \mathrm{g} / \mathrm{ml})$ and incubated at $37^{\circ} \mathrm{C}$ for $18 \mathrm{~h}$. Following the enzymatic treatments, a $60 \%$ TCA solution was added to a final concentration of $120 \mathrm{~g} / \mathrm{l}$ and the mixture was kept under mild stirring for $30 \mathrm{~min}$ at room temperature. Proteins and breakdown products were precipitated by centrifugation $\left(10000 \mathrm{~g}, 4^{\circ} \mathrm{C}, 30 \mathrm{~min}\right)$ and the supernatant was neutralised, dialysed and lyophilised as formerly described.

The protein content of the purified EPS fraction was measured using the commercial BCA protein assay kit (Pierce, IL. USA) following the manufacturer's instructions.

The EPS yield, molar mass distribution and radius of the molecule were determined by means of size exclusion chromatography (SEC). Samples were dissolved at $5 \mathrm{mg} / \mathrm{ml}$ in $100 \mathrm{~mm}-\mathrm{NaNO}_{3}$ and separated in two columns placed in series: TSK-Gel G3000 PW $\mathrm{XL}_{\mathrm{XL}}+$ TSK-Gel G5000 PW $\mathrm{XL}$ protected with a TSK-Gel guard column (Supelco-Sigma). The mobile phase was $100 \mathrm{~mm}-\mathrm{NaNO}_{3}$ and the separations took place at $40^{\circ} \mathrm{C}$ at a flow rate of $0.45 \mathrm{ml} / \mathrm{min}$. The aforementioned HPLC apparatus was employed coupled with a third detector, the multi-angle laser light scattering (MALLS) Dawn Heleos II (Wyatt Europe GmbH, Dembach, Germany). The EPS yield was calculated from the data obtained with the RI detector by using the corresponding regression equations obtained from dextran standards and the PDA detector set at $280 \mathrm{~nm}$ was used to check the absence of protein in the EPS peak (Salazar et al. 2009). The weight average molar mass (Mw) and the weight average radius ( $R w)$ of the EPS were directly measured with the MALLS detector.

The monosaccharide composition of the two EPS fractions was determined after hydrolysis with $3 \mathrm{M}$-trifluoroacetic acid (TFA), conversion in their corresponding alditol acetates and separation by gas-liquid chromatography (GLC) as described by Salazar et al. (2009). The linkage types present in the EPS molecule were determined after methylation of the EPS according to the procedure described by Ciucanu \& Kerek (1984). The permethylated polysaccharide was hydrolyzed with $3 \mathrm{M}$-TFA, and the monosaccharides released were reduced with $\mathrm{NaBD}_{4}$ and then acetylated to give corresponding partially methylated alditol acetates, which were analysed by GLC-MS under conditions previously described (Leal et al. 2008). Analyses were carried out at "Centro de Investigaciones Biológicas" (CIB-CSIC, Madrid).

\section{Gastrointestinal survival of strains}

Resistance to the chemically simulated gastric and intestinal conditions. The survival of the strains in the GIT situation was studied by an in vitro model that chemically simulates the physiological conditions (Sánchez et al. 2010). The following solutions were used: (i) simulated gastric juice containing $125 \mathrm{~mm}-\mathrm{NaCl}, 7 \mathrm{~mm}-\mathrm{KCl}, 45 \mathrm{~mm}-\mathrm{NaHCO}_{3}$, and $0.3 \%(\mathrm{w} / \mathrm{v})$ pepsin (Sigma) $\mathrm{pH} 2.0$ adjusted with $\mathrm{HCl}$, (ii) simulated duodenal juice containing $1 \%(\mathrm{w} / \mathrm{v})$ bovine bile (Sigma) pH 8.0 adjusted with $10 \mathrm{~mm}-\mathrm{NaOH}$, and (iii) simulated ileal juice containing $0.3 \%(\mathrm{w} / \mathrm{v})$ bovine bile, and $0 \cdot 1 \%(\mathrm{w} / \mathrm{v})$ pancreatin (Sigma) $\mathrm{pH} 8 \cdot 0$ adjusted with $10 \mathrm{~mm}-\mathrm{NaOH}$. To simulate the GIT conditions, cells from $24 \mathrm{~h}$ MRS-grown cultures of the parental and bile-resistant derivative strains were harvested by centrifugation $(10000 \mathrm{~g}$, $15 \mathrm{~min}, 5^{\circ} \mathrm{C}$ ), washed twice with a solution of $8.5 \mathrm{~g} \mathrm{NaC} / \mathrm{l}$ and concentrated 10 -fold. For each strain, $100 \mu \mathrm{l}$ of the concentrated suspensions were centrifuged and resuspended either in $1 \mathrm{ml}$ of simulated gastric juice or in $1 \mathrm{ml}$ of simulated gastric juice containing $200 \mathrm{~g}$ skimmed milk/l, which increased the $\mathrm{pH}$ of the bacterial suspension to about 4.5. Bacterial suspensions were then incubated for $90 \mathrm{~min}$ at $37^{\circ} \mathrm{C}$ with a mild stirring (200 rpm). Afterwards, cells were harvested $(10000 \mathrm{~g}, 15 \mathrm{~min})$, resuspended in the simulated duodenal juice and incubated for $10 \mathrm{~min}$ at $37^{\circ} \mathrm{C}$ in an anaerobic chamber (Mac 500, Down Whitley Scientific, West Yorkshire, UK) under $10 \% \mathrm{H}_{2}, 10 \% \mathrm{CO}_{2}$, and $80 \% \mathrm{~N}_{2}$ atmosphere. After this step, cells were centrifuged again, resuspended in the simulated ileal juice and incubated for $90 \mathrm{~min}$ at $37^{\circ} \mathrm{C}$ in anaerobic conditions. Viable cell counts were obtained from the initial cultures and after the simulation of each condition tested and results were expressed as log cfu/ml.

Adhesion to the epithelial intestinal cell line HT-29-MTX. The adhesion capability of the strains was assessed with the epithelial intestinal cell line HT29-MTX that is able to constitutively produce mucin (Lesuffleur et al. 1990). The cell line was maintained in supplemented DMEM (Sigma) using standard procedures (Sanchez et al. 2010). For experiments, $1 \times 10^{5}$ cells $/ \mathrm{ml}$ were seeded in 24 -well plates and incubated to confluence for $13 \pm 1$ day (about $1 \times 10^{7}$ cells $/ \mathrm{ml}$ ). The cell line was used between passes 26 and 28 .

Bacterial suspensions were obtained from $24 \mathrm{~h}$ cultures of parental and bile-resistant derivative grown in MRS with different concentrations of bovine bile salts: the parental strain 193 was cultured in the presence of $0 \%, 0 \cdot 1 \%$ and $0 \cdot 3 \%$ of bile and the derivative $193+$ with $0 \%, 0 \cdot 3 \%$ and $0.5 \%$ of bile. Bacteria were harvested from cultures by 
centrifugation $\left(10000 \mathrm{~g}, 15 \mathrm{~min}, 5^{\circ} \mathrm{C}\right)$, washed twice with PBS buffer and resuspended in DMEM without antibiotics at a concentration of about $1 \times 10^{8} \mathrm{cfu} / \mathrm{ml}$. Bacterial counts in MRS-agar were performed in order to determine the number of bacteria added. HT29-MTX monolayers were washed twice with Dulbecco's PBS buffer (Sigma-Aldrich) to remove the antibiotics and then bacterial suspensions were added in a ratio of epithelial cells: bacteria of 1:10. Plates were incubated for $1 \mathrm{~h}$ at $37^{\circ} \mathrm{C}, 5 \% \mathrm{CO}_{2}$ in a Heracell ${ }^{\circledR} 240$ incubator (Thermo Electron LDD $\mathrm{GmbH}$, Langenselbold, Germany). After the incubation period, supernatant was removed and wells were softly washed three times with Dulbecco's PBS buffer to remove the non-attached bacteria. Finally, the monolayers were trypsinised and bacterial counts were carried out to determine the number of adhered bacteria. Results were expressed as the percentage of adhered bacteria with respect to the amount of bacteria added.

\section{Statistical analyses}

Data were statistically analyzed by means of one-way ANOVA tests using the SPSS 11.0 software for Windows (SPSS Inc., Chicago, IL). Tests were performed employing the strain as factor, with two categories: parental and derivative. For simulated gastric and intestinal transit, an additional ANOVA test was carried out using the presence and absence of milk as categories within each strain and gastric or intestinal condition tested.

\section{Results and Discussion}

\section{Growth and metabolic activity of strains in milk}

Main growth and metabolic activity parameters of Lb. delbrueckii subsp. lactis 193 and its bile resistant derivative $L b$. delbrueckii subsp. lactis $193+$ in milk are shown in Table 1. Lb. delbrueckii subsp. lactis 193 was able to grow and acidify milk efficiently at the expenses of lactose consumption, with accumulation of galactose. The apparent imbalance obtained between lactose consumed and galactose released and lactic acid formed, inferred from data presented in Table 1, may be attributed to limitations of the chromatographic separation of the different compounds and to the different sensitivity of detectors used for quantification (RI for sugars and PDA in the case of lactic acid). Production of acetaldehyde by the strain 193 was considerably higher than ethanol formation. Acetaldehyde is one of the main contributors to flavour in fermented milks and certain cheeses (Cogan, 1995; Qian \& Reineccius, 2003; Pinto et al.2009). In spite of the wide variation reported in literature on the profile of flavour compounds of different strains within the same species of $L A B$, values obtained by us were in the range of those previously reported for $L b$. delbrueckii in milk which commonly produces more
Table 1. Growth and metabolic activity parameters of Lactobacillus delbrueckii subsp. lactis 193 and its bile-resistant derivative strain $193+$ in pasteurised milk incubated at $37^{\circ} \mathrm{C}$ for $18 \mathrm{~h}$. ANOVA: *** $P<0.001$

\begin{tabular}{|c|c|c|}
\hline Parameter & Strain & Mean \pm SD \\
\hline \multirow[t]{2}{*}{$\mathrm{pH}$} & 193 & $4 \cdot 91 \pm 0 \cdot 05$ \\
\hline & $193+$ & $4 \cdot 73 \pm 0 \cdot 17$ \\
\hline \multirow[t]{2}{*}{ Increment log cfu/ml } & 193 & $1 \cdot 28 \pm 0 \cdot 38$ \\
\hline & $193+$ & $1 \cdot 71 \pm 0 \cdot 22$ \\
\hline \multirow[t]{2}{*}{ Lactose consumption (mM) } & 193 & $25 \cdot 05 \pm 9 \cdot 95$ \\
\hline & $193+$ & $21 \cdot 90 \pm 2 \cdot 35$ \\
\hline \multirow[t]{2}{*}{ Galactose released (mM) } & 193 & $27 \cdot 45 \pm 2 \cdot 85$ \\
\hline & $193+$ & $28 \cdot 30 \pm 2 \cdot 05$ \\
\hline \multirow[t]{2}{*}{ Lactic acid formed (mM) } & 193 & $68 \cdot 40 \pm 7 \cdot 85$ \\
\hline & $193+$ & $69 \cdot 75 \pm 5 \cdot 35$ \\
\hline \multirow[t]{2}{*}{ Acetaldehyde $(\mu \mathrm{g} / \mathrm{ml})$} & 193 & $16 \cdot 15 \pm 2 \cdot 37$ \\
\hline & $193+$ & $\begin{array}{l}3 \cdot 46 \pm 0 \cdot 29 \\
* * *\end{array}$ \\
\hline \multirow[t]{2}{*}{ Ethanol $(\mu \mathrm{g} / \mathrm{ml})$} & 193 & $3 \cdot 63 \pm 0 \cdot 15$ \\
\hline & $193+$ & $\begin{array}{c}20 \cdot 15 \pm 1 \cdot 43 \\
* * *\end{array}$ \\
\hline \multirow[t]{2}{*}{ EPS yield (mg/l) } & 193 & $24 \cdot 06 \pm 0 \cdot 06$ \\
\hline & $193+$ & $\begin{array}{c}37 \cdot 19 \pm 0 \cdot 97 \\
* * *\end{array}$ \\
\hline \multirow[t]{2}{*}{ Apparent viscosity (s) } & 193 & $101 \cdot 67 \pm 1 \cdot 70$ \\
\hline & $193+$ & $\begin{array}{c}73 \cdot 75 \pm 1 \cdot 50 \\
* * *\end{array}$ \\
\hline
\end{tabular}

acetaldehyde than ethanol (Cogan, 1995; Beshkova et al. 1998; Shene \& Bravo, 2007; Pinto et al. 2009).

Adaptation to bile of sensitive strains has been proposed as a suitable way of overcoming the deleterious action of these compounds on beneficial strains intended to be used in human foods (Sarkar, 2010). Although the species $L b$. delbrueckii is not considered a probiotic, some health beneficial properties could derive from products containing LAB starters (Cenci et al. 2002; Cogan et al. 2007). Therefore, we compared growth and metabolic properties in milk of the bile-adapted strain $L b$. delbrueckii subsp. lactis $193+$ with respect to the bile-sensitive parental strain 193. No significant differences were found for $\mathrm{pH}$ values, lactose consumed, galactose released and lactic acid formed. However, formation of volatile compounds was markedly different between both strains. Notably, the production of ethanol by the bile-resistant derivative 193 + surpassed the production of acetaldehyde, levels of this last compound being considerably lower than those of the parental strain $(P<0 \cdot 001)$. Ethanol production by LAB occurs at the expense of enzymatic reduction of acetaldehyde (Axelsson, 2004); this reaction is usually unsuitable for yoghurt and dairy product production since flavour development may be negatively affected (Pinto et al. 2009). In a similar way, Sánchez et al. (2010) found higher concentrations of ethanol and lower concentrations of acetaldehyde at the end of the cold storage period of fermented milks made with starter cultures and a bile-resistant derivative strain of Bifidobacterium animalis compared with products obtained 
with the parental strain. Relating to this, we have recently shown that adaptation to bile of the strain $L b$. delbrueckii subsp. lactis 200 promoted a shift in the final products of glucose catabolism in MRS culture leading to an increase in the lactic/acetic acids ratio (Burns et al. 2010). Shifts in the catabolism of carbohydrates found in the present work, although not suitable for the development of sensory properties of dairy products, could however play an important physiological role in the bacterium. Thus, the reduction of pyruvate to lactic acid allows bacterial cells the regeneration of $2 \mathrm{~mol} \mathrm{NAD+per} \mathrm{mol} \mathrm{of} \mathrm{glucose} \mathrm{consumed,}$ whereas the conversion to ethanol provides 2 additional mol of regenerated NAD+. Therefore, it can be speculated that an increase of ethanol production may represent a mechanism of $L b$. delbrueckii subsp. lactis $193+$ to cope with oxidative stress imposed by bile salts, as has been previously suggested in other lactobacilli and bifidobacteria (Bron et al. 2004; Sánchez et al. 2006; Lee et al. 2008; Sánchez et al. 2008).

Lb. delbrueckii subsp. lactis 193 and 193+ provided fermented milk with a smooth and creamy consistency, a desirable property for application in low-fat cheese making and manufacture of fermented milks (Ruas-Madiedo et al. 2009c). The high apparent viscosity in milk fermented by the strains under study strongly suggested that they were able to synthesize EPS. The viscosity-intensifying capability in milk of the strains 193 and 193 + was higher than that of traditional viscosifying yoghurt starter cultures containing Lb. delbrueckii subsp. bulgaricus and Streptococcus thermophilus strains (van Marle \& Zoon, 1995) and both viscosifying capability and EPS yield were comparable to that of HePS from other lactobacilli and lactococci from different origins (Ruas-Madiedo et al. 2002. 2005; Mozzi et al. 2006; Salazar et al. 2009). Remarkably, the apparent viscosity of fermented milk made with the strain 193 was significantly higher, and EPS yield significantly lower $(P<0 \cdot 001)$, than that of fermented milks made with the bile resistant strain 193 + ; this suggests that the acquisition of bile resistance may have introduced some modifications in the composition/ structure of the polymer that could have impaired its technological properties.

\section{Physico-chemical characterisation of the EPS produced in milk}

The synthesis in milk of viscosifying EPS is a property of great interest for improving the consistency of fermented milks and cheeses in a natural way. Firstly we characterized the EPS produced in milk by the strains under study (Table 2). The EPS fraction produced by $L b$. delbrueckii subsp. lactis 193 presented a unique peak of high Mw (about $10^{6} \mathrm{Da}$ ). This polymer was a HePS composed of glucose and galactose in a ratio 1:1. Mozzi et al. (2006) reported that most HePS produced by mesophilic and thermophilic lactobacilli from food origin displayed a unique EPS peak of Mw lower than $10^{6} \mathrm{Da}$, mostly composed of galactose and glucose. In contrast, Salazar et al. (2009) found that the presence of
Table 2. Physico-chemical characteristics of the EPS fractions isolated from Lactobacillus delbureckii subsp. lactis 193 and its bileresistant derivative $193+$

$\begin{array}{llcc} & & \text { EPS 193 } & \text { EPS } 193+ \\ \text { Molar mass (Mw) } & (\mathrm{Da}) & 1 \cdot 3 \times 10^{6} & 1 \cdot 5 \times 10^{6} \\ \text { Radius of gyration }(\mathrm{Rw}) & (\mathrm{nm}) & 56 \cdot 8 & 63 \cdot 1 \\ \text { Monosaccharide ratio } & \text { Glucose } & 1 & 1 \\ & \text { Galactose } & 1 & 1\end{array}$

Table 3. Main sugar linkage types present in the EPS fractions isolated from Lactobacillus delbureckii subsp. lactis 193 and its bileresistant derivative $193+$. Galp: galactose residue in pyranose conformation, Galf: galactose residue in furanose conformation, Glcp: glucose residue in pyranose conformation

Percentage

$\begin{array}{lll}\text { Linkage type } & \text { EPS } 193 & \text { EPS } 193+ \\ \text { 1,3 Galp } & 42 \cdot 5 & 38 \cdot 0 \\ \text { 1,3 Glcp } & 21 \cdot 3 & 18 \cdot 6 \\ \text { 1,6 Glcp } & 19 \cdot 3 & 17 \cdot 3 \\ \text { 1,2 Galf } & 3 \cdot 3 & 10 \cdot 5\end{array}$

two peaks of high and low Mw is a common feature in EPS from bifidobacteria and lactobacilli of intestinal origin. No noticeable differences in $\mathrm{Mw}, \mathrm{Rw}$ and monosaccharide composition were found between the EPS produced by the parental strain 193 and its bile resistant derivative $193+$. Percentage of most linkage types found were similar in both strains, however notably the percentage of 1,2 Galf was higher in the bile resistant derivative $193+$ than in the parental strain 193 (Table 3). Since this is the sole difference found by us between polymers of both strains, this suggests that the repeating unit of EPS 193 + may differ from that of EPS 193. Relating to this, we have recently reported variations in Mw of EPS fractions as well as in monosaccharide ratios between polymers synthesized by a bileresistant Bifido. animalis strain and its parental sensitive strain (Ruas-Madiedo et al. 2010). Whether these are changes linked to the acquisition of bile tolerance or they are just pleiotropic phenomena, is at present unknown. The physiological and ecological significance of these variations in the characteristics of EPS produced by bile resistant derivatives deserves further investigation.

It has been indicated that linkage type into the backbone of repeating unit building HePS, as well as the presence of side chains or the branching degree, among others, are parameters contributing to the viscosity intensifying ability of these polymers in fermented milks (Ruas-Madiedo et al. 2002). Differences in percentage of linkage types could partly contribute to differences found in technological properties between the polymers produced by the sensitive and bile resistant derivative strains 193 and $193+$. Other factors such as $\mathrm{Mw}$, interactions between the EPS and the 
Log cfu/ml Buffer

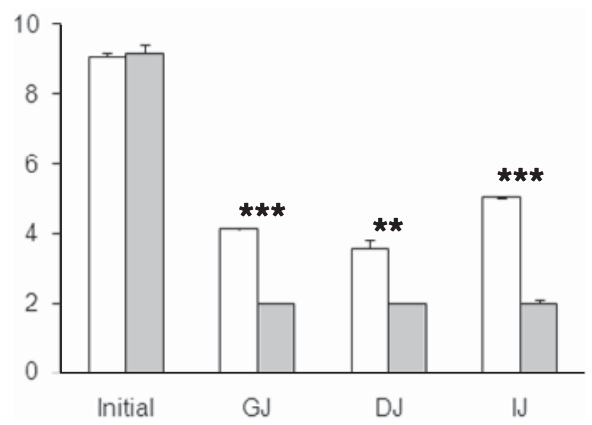

Buffer $+20 \%$ skim-milk

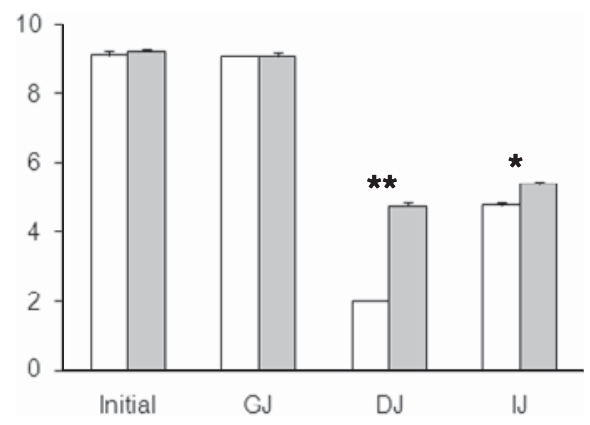

Fig. 1. Counts (log cfu/ml) of Lactobacillus delbrueckii subsp. lactis 193 (white bars) and its bile-resistant derivative strain Lb. delbrueckii subsp. lactis $193+$ (grey bars) after chemical simulation of gastrointestinal conditions. GJ: simulated gastric juice, DJ: simulated duodenal juice, IJ: simulated ileal juice. ANOVA: ${ }^{*} P<0 \cdot 05,{ }^{* *} P<0 \cdot 01,{ }^{* * *} P<0 \cdot 001$.

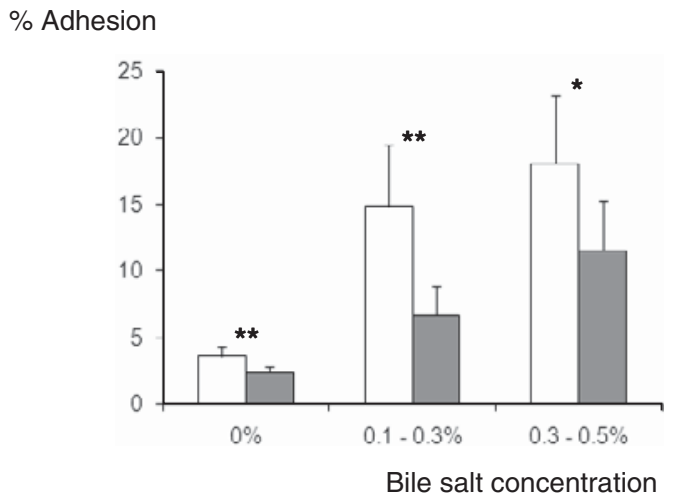

Fig. 2. Adhesion (\% counts of bacteria adhered with respect to bacteria added) to the epithelial intestinal cellular line HT29-MTX of Lactobacillus delbrueckii subsp. lactis 193 (white bars) and its bile-resistant derivative strain Lb. delbrueckii subsp. lactis $193+$ (grey bars) in the presence of different concentrations of bile salts. ANOVA: $* P<0 \cdot 05, * * P<0 \cdot 01$.

milk protein network (Hassan, 2008) or the acidification rate of the strains in milk (Lucey \& Singh, 1998), among others, could also affect the viscosity of the fermented milk.

\section{Survival of strains in simulated GIT conditions}

Survival through the GIT may be a positive feature of microorganisms included in foods in order to reach the intestine alive. Therefore, the survival in simulated gastric, duodenal, and ileal juices, and the influence of milk on this process, was tested for both strains studied. Simulated gastric juice caused a decrease in the population of $L b$. delbrueckii subsp. lactis 193 of ca. 5 log orders, although viable cells (about 5 log orders) were still observed at the end of the sequential passage through the different solutions (Fig. 1). Viability losses were in accordance with those previously reported for other strains of the same species (Vinderola \&
Reinheimer, 2003; Burns et al. 2010). The presence of skimmed milk counteracted the detrimental effect of simulated gastric juice on cell viability and improved the survival of the strain 193 in these conditions. However, no survival improvement was observed with skimmed milk for the subsequent steps (duodenal and ileal simulated juices, statistical analysis not shown). An increase of viable cell counts was found in ileal juice with respect to counts in duodenal juice either with and without skimmed milk which may be attributed to the transition from viable non-cultivable to viable cultivable state of cells (Lahtinen et al. 2006) probably favoured by lower concentrations of bile in simulated ileal juice compared with simulated duodenal juice. With respect to the strain $193+$, exposure to simulated gastric and intestinal juices caused a viability loss of about 7 log units, and no improvement in survival was found with respect to the parental strain 193, which was coincident with results previously reported by us for other strains of the same species (Burns et al. 2010). The presence of skimmed milk improved the survival of the strain $193+$ in simulated duodenal and ileal juices (significant differences at $P<0.01$; statistical analysis not shown) (Fig. 1). In spite of all this, considering jointly the two conditions tested in the present work (i.e. buffer and buffer + milk) the survival of Lb. delbrueckii subsp. lactis 193 and $193+$ in simulated duodenal and ileal juices was similar, indicating that the acquisition of bile resistance did not actually provide an improvement of survival in simulated gastric and intestinal conditions. In contrast, Sánchez et al. (2010) reported an increase in the survival in simulated GIT conditions of a Bifido. animalis bile-resistant derivative with respect to its bile-sensitive parental strain. Additionally, Burns et al. (2011) reported a higher survival of the bile-resistant derivative $L b$. delbrueckii subsp. lactis $200+$ in the intestinal fluid of mice compared with the parental bile-sensitive strain Lb. delbrueckii subsp. lactis 200. Different behaviour of bile-resistant derivatives could reflect physiological and molecular differences derived from their adaptation to this stress factor. 
The ability to transiently colonize the gut surfaces is related to the ability of microorganisms to adhere to mucus or intestinal epithelial cells. Adhesion to the intestinal cell line HT29-MTX at different bile salt concentrations was assessed (Fig. 2). The strains 193 and 193+ displayed a lower adhesion capacity (about 3.5 and $2.5 \%$, respectively) than other lactobacilli (Schillinger et al. 2005; Burns et al. 2010). Adhesion of both microorganisms clearly rose in the presence of bile salts (statistical analysis not shown) although the derivative $193+$ was significantly less adhesive $(P<0 \cdot 01)$ than its parental counterpart. Differences between parental and derivative strains may be due to changes in surface properties that have been shown to occur in other microorganisms such as some lactobacilli and bifidobacteria as a consequence of the acquisition of bile salt resistance (Gomez-Zavaglia et al. 2002; Gueimonde et al. 2005; Ruiz et al. 2007). The behaviour of these two strains was different from that found for the bile sensitive/bile resistant pair Lb. delbrueckii subsp. lactis 200 and $200+$ since, in that case, adhesion values clearly diminished in the presence of bile (Burns et al. 2010). These differences between both pairs of microorganisms could account for different surface molecules involved in cellular adhesion of 193/193+ and 200/200+.

Although it has traditionally been considered that yoghurt starters do not survive the GIT, some recent studies seem to indicate that certain strains do at a reduced extent (Lick et al. 2001; Mater et al. 2005; Elli et al. 2006; Burns et al. 2010). From our results, it could be assumed that both strains of Lb. delbrueckii subsp. lactis tested in the present work could survive simulated gastric and intestinal conditions in certain numbers when they are ingested within a food matrix. In contrast to that observed in some bifidobacteria and lactobacilli in which the acquisition of bile resistance improved some functional properties (Sánchez et al. 2008, 2010; Burns et al. 2011), in the case of $L b$. delbrueckii subsp. lactis 193, the acquisition of resistance to bile does not seem to provide any improvement in the viability and adhesion in simulated gastric and intestinal conditions.

In short, Lb. delbrueckii subsp. lactis 193 presents suitable properties for the manufacture of fermented dairy products and produces a HePS that confers viscosity intensifying properties to milk. The acquisition of a stable bile-resistant phenotype does not improve any of the properties tested. Thus, the use of bile-resistant derivative strains should be carefully evaluated in each specific application considering the influence that the acquisition of a stable bile-resistant phenotype could have in the viability and technological properties of microorganisms.

This work was financed by FEDER funds (European Union) and the Spanish Plan Nacional de I+D through projects AGL200762736, AGL2009-09445, and AGL2010-16525. Patricia Burns was funded by a 6-month grant from the Agencia Española de Cooperación Internacional for a research stay at IPLA-CSIC. Groups from Spain and Argentina shared a joint collaboration project CSIC-CONICET (reference 2005AR0047). Ana María
Hernández-Barranco from IPLA-CSIC and Alicia Prieto from CIB-CSIC are acknowledged for their excellent technical assistance in the GLC and GC-MS analyses. The cellular line HT29-MTX was kindly supplied by Dr. T. Lesuffleur (INSERM U843 Paris, France).

\section{References}

Axelsson L 2004 Lactic Acid Bacteria: classification and physiology. In Lactic Acid Bacteria: Microbiological and Functional Aspects, Third Edition, pp 1-66 (Ed. S Salminen, A. von Wright \& A Ouwehand). New York, USA: Marcel Dekker Inc

Beshkova D, Simova E, Frengova G \& Simov Z 1998 Production of flavour compounds by yogurt starter cultures. Journal of Industrial Microbiology \& Biotechnology 20 180-186

Bron PA, Marco M, Hoffer SM, Van Mullekom E, de Vos WM \& Kleerebezem M 2004 Genetic characterization of the bile salt response in Lactobacillus plantarum and analysis of responsive promoters in vitro and in situ in the gastrointestinal tract. Journal of Bacteriology 1867829 7835

Burns P, Sánchez B, Vinderola G, Ruas-Madiedo P, Ruiz L, Margolles A, Reinheimer \& de los Reyes-Gavilán CG 2010 Inside the adaptation process of Lactobacillus delbrueckii subsp. lactis to bile. International Journal of Food Microbiology 142 132-141

Burns P, Vinderola G, Binetti A, Quiberoni A, de los Reyes-Gavilán CG \& Reinheimer JA 2008 Bile-resistant derivatives obtained from nonintestinal dairy lactobacilli. International Dairy Journal 18 377-385

Burns P, Vinderola G \& Reinheimer J 2011 Impact of bile salt adaptation of L. delbrueckii subsp. lactis 200 on its interaction capacity with the gut. Research in Microbiology (submitted for publication)

Cenci G, Rossi J, Trotta F \& Caldini G 2002 Lactic acid bacteria isolated from dairy products inhibit genotoxic effect of 4-nitroquinoline-1-oxide in SOS-chromotest. Systematic and Applied Microbiology 25 483-490

Ciucanu I \& Kerek F 1984 A simple and rapid method for the permethylation of carbohydrates. Carbohydrate Research 131 209-217

Cogan TM 1995 Flavor production by dairy starter cultures. Journal of Applied Bacteriology 79 S49-S64

Cogan TM, Beresford TP, Steele J, Broadbent J, Shah NP \& Ustunol Z 2007 Advances in starter cultures and cultured foods. Journal of Dairy Science 90 4005-4021

Elli M, Callegari ML, Ferrari S, Bessi E, Cattivelli D, Soldi S, Morelli L, Goupil Feuillerat N \& Antoine JM 2006 Survival of yogurt bacteria in the human gut. Applied and Environmental Microbiology 72 5113-5117

Gilliland SE 1998 Fermented milks and probiotics: Applied Dairy Microbiology, pp 195-212 (Ed. EH Marth \& JL Steel). New York, USA: Marcel Dekker Inc

Giraffa G, de Vecchi P \& Rossetti L 1998 Note: Identification of Lactobacillus delbrueckii subspecies bulgaricus and subspecies lactis dairy isolates by amplified rDNA restriction analysis. Journal of Applied Microbiology $\mathbf{8 5}$ 918-924

Gómez-Zavaglia A, Kociubinski G, Perez P, Disalvo E \& DeAntoni G 2002 Effect of bile on the lipid composition and surface properties of bifidobacteria. Journal of Applied Microbiology 93 794-799

Gueimonde M, Noriega L, Margolles A, de los Reyes-Gavilán CG \& Salminen S 2005 Ability of Bifidobacterium strains with acquired resistance to bile to adhere to human intestinal mucus. International Journal of Food Microbiology 101 341-346

Guglielmotti D, Briggiler Marcó M, Vinderola C, de los Reyes-Gavilán CG, Reinheimer J \& Quiberoni A 2007 Spontaneous Lactobacillus delbrueckii phage-resistant mutants with acquired bile tolerance. International Journal of Food Microbiology 119 236-242

Hassan AN 2008 ADSA Foundation Scholar Award: Possibilities and challenges of exopolysaccharide-producing lactic cultures in dairy foods. Journal of Dairy Science 91 1282-1298

Hebert EM, Mamone G, Picariello G, Raya RR, Savoy G, Ferranti P \& Addeo F 2008 Characterization of the pattern of alpha(s1)- and beta-casein breakdown and release of a bioactive peptide by a cell envelope 
proteinase from Lactobacillus delbrueckii subsp. lactis CRL 581. Applied and Environmental Microbiology 74 3682-3689

Hellinga C, Somesen DJ \& Koenraads JPJM 1989 Viscosity of stirred yoghurt: modern techniques useful in analysing and improving routine measurements. Netherland Milk and Dairy Journal 40 217-240

Lahtinen SJ, Ouwehand AC, Reinikainen JP, Korpela JM, Sandholm J, \& Salminen SJ 2006 Intrinsic properties of so-called dormant probiotic bacteria, determined by flow cytometric viability assays. Applied and Environmental Microbiology 72 5132-5134

Leal JA, Jimenez-Barbero J, Bernabé M \& Prieto A 2008 Structural elucidation of a cell wall fungal polysaccharide isolated from Ustilaginoidea virens, a pathogenic fungus of Oriza sativa and Zea mays. Carbohydrate Research 343 2980-2984

Lee K, Lee HG \& Choi YJ 2008 Proteomic analysis of the effect of bile salts on the intestinal and probiotic bacterium Lactobacillus reuteri. Journal of Biotechnology 137 14-19

Lesuffleur T, Barbat A, Dussaulx E \& Zweibaum A 1990 Growth adaptation to methotrexate of HT-29 human colon-carcinoma cells is associated with their ability to differentiate into columnar and mucus-secreting cells. Cancer Research 50 6334-6343

Lick S, Drescher K \& Heller KJ 2001 Survival of Lactobacillus delbrueckii subsp. bulgaricus and Streptococcus thermophilus in the terminal ileum of fistulated Göttingen minipigs. Applied and Environmental Microbiology 67 4137-4143

Lucey JA \& Singh H 1998 Formation and physical properties of acid milk gels: a review. Food Research International 30 529-542

Marteau P, Minekus M, Havenaar R \& Huis In't Veld JHJ 1997 Survival of lactic acid bacteria in a dynamic model of the stomach and small intestine: validation and the effects of bile. Journal of Dairy Science $\mathbf{8 0}$ 1031-1037

Mater DDG, Bretigny L, Firmesse O, Flores MJ, Mogenet A, Bresson JL \& Corthier G 2005 Streptococcus thermophilus and Lactobacillus delbrueckii subsp. bulgaricus survive gastrointestinal transit of healthy volunteers consuming yogurt. FEMS Microbiology Letters 250 185-187

Mozzi F, Vaningelgem F, Hébert EM, van der Meulen R, Moreno MRF, de Valdez GF \& De Vuyst L 2006 Diversity of heteropolysaccharidesproducing lactic acid bacterium strains and their biopolymers. Applied and Environmental Microbiology 72 4431-4435

Noriega L, Gueimonde M, Sánchez B, Margolles A \& de los Reyes-Gavilán CG 2004 Effect of the adaptation to high bile salts concentrations on glycosidic activity, survival at low $\mathrm{pH}$ and cross-resistance to bile salts in Bifidobacterium. International Journal of Food Microbiology 94 79-86

Pinto SM, das Graças Clemente M \& Ronaldo de Abreu L 2009 Behaviour of volatile compounds during the shelf life of yogurt. International Journal of Dairy Technology 62 215-223

Qian M \& Reineccius G 2003 Potent aroma compounds in Parmigiano Reggiano cheese studied using a dynamic headspace (purge-trap) method. Flavour and Frangrance Journal 18 252-259

Ruas-Madiedo P, Alting AC \& Zoon P 2005 Effect of exopolysaccharides and proteolytic activity of Lactococcus lactis subsp. cremoris strains on the viscosity and structure of fermented milks. International Dairy Journal 15 155-164

Ruas-Madiedo P, Gueimonde M, Arigoni F, de los Reyes-Gavilán CG \& Margolles A 2009a Bile affects the synthesis of exopolysaccharides by Bifidobacterium animalis. Applied and Environmental Microbiology $\mathbf{7 5}$ 1204-1207
Ruas-Madiedo P, Medrano M, Salazar N, de los Reyes-Gavilán CG, Pérez PF \& Abraham A 2010 Exopolysaccharides produced by Lactobacillus and Bifidobacterium strains abrogate in vitro the cytotoxic effect of bacterial toxins on eukaryotic cells. Journal of Applied Microbiology 1092079 2086

Ruas-Madiedo P, Salazar N \& de los Reyes-Gavilán CG 2009b Biosynthesis and biochemical analysis of exopolysaccharides produced by lactic acid bacteria. In Bacterial polysaccharides: current innovations and future trends, pp 279-310 (Ed. M Ullrich). Pittsburg (Pennsylvania), USA: Caister Academic Press

Ruas-Madiedo P, Salazar N \& de los Reyes-Gavilán CG 2009c Exopolysaccharides produced by lactic acid bacteria in food and probiotic applications. In Microbial Glycobiology: structures, relevance and applications, pp 887-902 (Eds. A Moran, P Brennan, O Holst, M von Itzstein). San Diego, CA, USA: Elsevier

Ruas-Madiedo P, Tuinier R, Kanning M \& Zoon P 2002 Role of exopolysaccharides produced by Lactococcus lactis subsp. cremoris on the viscosity of fermented milks. International Dairy Journal 12 689-695

Ruiz L, Sánchez B, Ruas-Madiedo P, de los Reyes-Gavilán CG \& Margolles A 2007 Cell envelope changes in Bifidobacterium animalis ssp.lactis as a response to bile. FEMS Microbiology Letters 274 316-322

Salazar N, Prieto A, Leal JA, Mayo B, Bada-Gancedo JC, de los ReyesGavilán CG \& Ruas-Madiedo P 2009 Production of exopolysaccharides by Lactobacillus and Bifidobacterium strains from human origin and metabolic activity of the producing bacteria in milk. Journal of Dairy Science 92 4158-4168

Sánchez B, de los Reyes-Gavilán CG \& Margolles A 2006 The $F_{1} F_{0}$-ATPase of Bifidobacterium animalis is involved in bile tolerance. Environmental Microbiology 8 1825-1833

Sánchez B, Fernández-García M, Margolles A, de los Reyes-Gavilán CG \& Ruas-Madiedo P 2010 Technological and probiotic selection criteria of a bile-adapted Bifidobacterium animalis subsp. lactis strain. International Dairy Journal 20 800-805

Sánchez B, Ruíz L, de los Reyes-Gavilán CG \& Margolles A 2008 Proteomics of stress response in Bifidobacterium. Frontiers in Biosciences 136905 6919

Sarkar S 2010 Approaches for enhancing the viability of probiotics: a review. British Food Journal 112 329-349

Schillinger U, Guigas C \& Holzapfel WH 2005 In vitro adherence and other properties of lactobacilli used in probiotic yoghurt-like products. International Dairy Journal 15 1289-1297

Shene C \& Bravo S 2007 Whey fermentation by Lactobacillus delbrueckii subsp. bulgaricus for exopolysaccharide production in continuous culture. Enzyme and Microbial Technology 40 1578-1584

Tannock GW 2003 The intestinal microflora. In Gut flora: nutrition immunity and health, pp 1-23 (Eds. R Fuller \& G Perdigón). Oxford, UK: Backwell Press

van Marle ME \& Zoon P 1995 Permeability and rheological properties of microbially and chemically acidified skim-milk gels. Netherlands Milk and Dairy Journal 49 47-65

Vinderola G \& Reinheimer J 2003 Lactic acid starter and probiotic bacteria: a comparative 'in vitro' study of probiotic characteristics and biological barrier resistance. Food Research International 36 895-904

Wall R, Fitzgerald G, Hussey S, Ryan T, Murphy B, Ross P \& Stanton C 2007 Genomic diversity of cultivable Lactobacillus populations residing in the neonatal and adult gastrointestinal tract. FEMS Microbiology Ecology $\mathbf{5 9}$ $127-137$ 